\title{
Вмј Global Health Exploring the intergenerational effects of undernutrition: association of maternal height with neonatal, infant and under-five mortality in Bangladesh
}

\author{
Wajiha Khatun, ${ }^{1}$ Ashraful Alam, ${ }^{1}$ Sabrina Rasheed, ${ }^{2}$ Tanvir M Huda, ${ }^{1}$ \\ Michael J Dibley ${ }^{1}$
}

To cite: Khatun W, Alam A, Rasheed S, et al. Exploring the intergenerational effects of undernutrition: association of maternal height with neonatal, infant and under-five mortality in Bangladesh. BMJ Glob Health 2018:3:e000881. doi:10.1136/ bmjgh-2018-000881

Handling editor Sanni Yaya

- Additional material is published online only. To view please visit the journal online (http://dx.doi.org/10.1136/ bmjgh-2018-000881).

Received 9 April 2018 Revised 16 August 2018 Accepted 20 August 2018

\section{Check for updates}

(C) Author(s) (or their employer(s)) 2018. Re-use permitted under CC BY-NC. No commercial re-use. See rights and permissions. Published by BMJ.

${ }^{1}$ Sydney School of Public Health, University of Sydney, Sydney, New South Wales, Australia ${ }^{2}$ International Centre for Diarrhoeal Disease Research Bangladesh, Dhaka, Bangladesh

Correspondence to

Wajiha Khatun;

wajiha.khatun@gmail.com

\section{ABSTRACT}

Background Global or regional evidence showed maternal height as a strong predictor of child survival. However, there is limited information that confirms the intergenerational effect of short maternal height on the risk of offspring mortality in Bangladesh. Therefore, this study aimed to examine the association of maternal height with neonatal, infant and under-five mortality in Bangladesh.

Methods It was a pooled analysis of data from four rounds of Bangladesh Demographic and Health Surveys 2004, 2007 2011 and 2014. We included singleton children aged 0-59 months born to mothers aged $15-49$ years $(n=29698)$. Mothers were interviewed to collect data on maternal and child characteristics, and socio-demographic information. Maternal height was measured using an adjustable measuring board calibrated in millimetres. We used STATA V.14.2 and adjusted for the cluster sampling design. Multivariate 'Modified Poisson Regression' was performed using stepwise backward elimination procedures to examine the association between maternal height and child death Results In the adjusted model, every $1 \mathrm{~cm}$ increase maternal height was associated with a reduced risk of neonatal mortality (relative risk $(\mathrm{RR})=0.973,95 \% \mathrm{Cl} 0.960$ to 0.986$)$, infant mortality $(\mathrm{RR}=0.980,95 \% \mathrm{Cl} 0.969$ to 0.991 ) and under-five mortality ( $\mathrm{RR}=0.982,95 \% \mathrm{Cl} 0.972$ to 0.992 ). Children of the shortest mothers (height $<145$ $\mathrm{cm}$ ) had 1.73 times greater risk of neonatal mortality, about 1.60 times greater risk of infant mortality and 1.48 times greater risk of under-five mortality compared with those of tall mothers (height $\geq 155 \mathrm{~cm}$ ). Among the children of the shortest mothers (height $<145 \mathrm{~cm}$ ), the absolute probabilities for neonatal, infant and under-five mortality were $4.4 \%$, $6.0 \%$ and $6.5 \%$, respectively, while for the children of the tall mothers (height $\geq 155 \mathrm{~cm}$ ), the absolute probabilities for neonatal, infant and under-five mortality were $2.6 \%, 3.7 \%$, and $4.4 \%$, respectively.

Conclusion These findings suggest a robust intergenerational linkage between short maternal height and the risk of neonatal, infant and under-five mortally in Bangladesh.

\section{INTRODUCTION}

Globally, there has been substantial progress in child survival in the last two decades.

\section{Key questions}

What is already known?

- Short adult height is a consequence of the intergenerational effects of undernutrition.

- Short maternal height is associated with child mortality in low-income and middle-income countries.

What are the new findings?

- Maternal height has a robust inverse association with neonatal, infant and under-five mortality in Bangladesh.

- Short maternal height $(<145 \mathrm{~cm})$ has 1.73 times more risk for neonatal mortality, 1.60 times more risk for infant mortality and 1.48 times more risk for under-five mortality compared with the tallest maternal height group $(\geq 155 \mathrm{~cm})$.

\section{What do the new findings imply?}

- These findings imply a strong intergenerational linkage between short maternal height and the risk of offspring mortality at age $0-59$ months in Bangladesh.

Despite such advances, disparities exist in neonatal, infant and under-five mortality across regions and countries. More than $80 \%$ of global under-five deaths occur in South Asia and sub-Saharan Africa. ${ }^{1}$ In South Asia, Bangladesh has one of the highest under-five mortality rates with around 106000 children dead before 5 years of age in $2016 .{ }^{1}$

Maternal and child undernutrition are important underlying causes of neonatal and under-five mortality. Prior research revealed that nearly $45 \%$ of all under-five deaths were attributable to fetal growth retardation, stunting, wasting, vitamin A and zinc deficiencies and suboptimal breast feeding in low-income and middle-income countries (LMICs) in $2011 .{ }^{2}$ However, more than 1 in 10 of these under-five deaths was caused by fetal growth retardation (FGR) that is associated with 
maternal undernutrition and short stature. ${ }^{2}$ In LMICs, short maternal stature is associated with about 6.5 million term or preterm, small-for-gestational age (SGA) births, caused by FGR annually. ${ }^{3}$

Recently, two large studies that pooled data showed maternal height as a strong predictor of under-five mortality in LMICs. ${ }^{45}$ One of these studies showed that reductions in maternal height from the average of 155 $\mathrm{cm}$ gradually increased the risk of under-five mortality. ${ }^{4}$ Another study showed that children of mothers with short stature $(<145 \mathrm{~cm})$ had about 1.6 times higher risk of neonatal mortality and nearly 1.4 times higher risk of under-five mortality compared with those with taller mothers $(\geq 160 \mathrm{~cm}) .^{5}$

Recently, a few studies have assessed the determinants of child mortality in Bangladesh ${ }^{67}$ but none of these studies considered to measure the association between maternal height and risk of mortality among neonates, infants and under-five children in Bangladesh. Therefore, in this study, we examined the association of maternal height with neonatal, infant and under-five mortality adjusting for other maternal, child and socio-demographic covariates using a nationally representative sample. The findings of this study should help improve programmes and policies aimed at increasing survival among neonates and under-five children in Bangladesh by focusing attention on the effects of intergenerational undernutrition.

\section{METHODS}

\section{Data sources and sampling design}

In this analysis, we used the data from 2004, 2007, 2011 and 2014 Bangladesh Demographic and Health Surveys (BDHS). ${ }^{8}$ Demographic and health surveys (DHS) are nationally representative sample surveys that collect information on demographic characteristics, and health and nutrition outcomes of the women and their children. ${ }^{9}$ The DHS sampling and household listing methods have been described elsewhere. ${ }^{10}$ In the BDHS, ever-married women aged 15-49 years were interviewed for data on women and children. The complete birth history of the respondents was recorded for all the live births. ${ }^{11}$ We used information from 29698 children who were born 5 years before the surveys conducted in 2004, 2007, 2011 and 2014. Trained interviewers measured the height of the women using standard wooden boards calibrated in millimetres. $^{12}$

\section{Conceptual framework}

This study used a conceptual framework for assessing the association between maternal height and neonatal, infant and under-five mortality. This framework was adapted from the ${ }^{13}$ UNICEF 2013 conceptual framework for determinants of child undernutrition ${ }^{13}$ based on available information in the BDHS data sets 2004, 2007, 20011 and 2014. Figure 1 presents the framework used in this study, along with the selected possible predictors of neonatal, infant and under-five mortality in Bangladesh.

\section{Primary outcome}

The primary outcomes of this study were neonatal, infant and under-five mortality. We have calculated the rate of mortality according to the measure of the infant and child mortality in DHS survey data. ${ }^{14}$ We define the rate of mortality as the number of deaths per thousand live births. Hence, we have estimated neonatal mortality as the proportion of the infants who died within the first month, infant mortality as the proportion of infants who died within aged 0-11 months and under-five mortality as the proportion of the children who died within aged 0-59 months.

\section{Main exposure}

The main exposure of our study was maternal height. In our analysis, we considered maternal height as a continuous variable to measure the mean height in centimetre and the effect of every $1 \mathrm{~cm}$ increase of maternal height on abovementioned primary outcomes. We also categorised maternal height as following categories: $\geq 155.0$ $\mathrm{cm}$ (the tallest group as reference), 154.9-150.0 cm, $149.9-145.0 \mathrm{~cm}$ and $<145.0 \mathrm{~cm}$ (the shortest group) and used these categories in our analysis. These categories were similar to those applied in two earlier maternal anthropometric studies, which measured the association between maternal height and child mortality. ${ }^{5}$ However, we modified the cut-off for the tallest maternal height category from $\geq 160.0 \mathrm{~cm}$ to $\geq 155.0 \mathrm{~cm}$. There were two reasons for this modification of the cut-off for the tallest (reference) group in our study. First, there was only a small number of observations in the category of maternal height $\geq 160.0 \mathrm{~cm} \quad(<5 \%$ of the total sample size). Second, there is evidence indicating that maternal height $<155.0$ $\mathrm{cm}$ increases the risk of under-five mortality. ${ }^{4}$

\section{Covariates}

We included nine covariates as the risk factors for child mortality, all of which earlier studies examined. ${ }^{15} 16 \mathrm{We}$ categorised these covariates as maternal-level, childlevel, household-level and community-level covariates. Maternal covariates considered were the maternal age at birth, maternal education and maternal occupation. Child covariates considered were child's sex, combined birth rank and interval. Household-level and community-level covariates considered were household wealth, husband's education, the location (rural or urban) and region of residence. We created a composite household wealth index from a list of household assets and facilities. All these variables were used as continuous variables and weighted using Principal Components Analysis (PCA) methods, and we calculated the household wealth index as the sum of the weighted score. ${ }^{17}$ We divided this wealth index in quintiles for categorical analyses. In our analysis, we also included time variable 'year of survey' and the variable 'recall period' constructed by calculating the differences from the date of interview to the child's date of birth. 


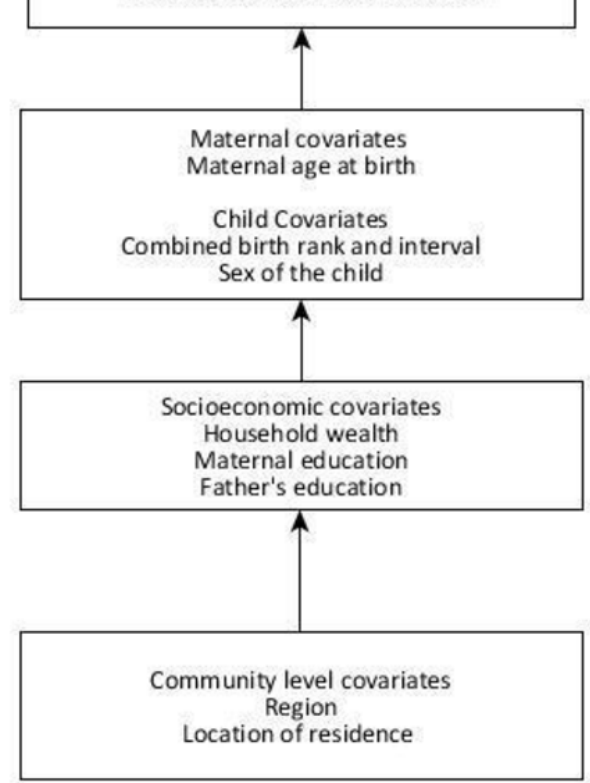

Figure 1 Conceptual framework for assessing an association between maternal height and neonatal, infant and under-five mortality. Adapted from UNICEF 2013.

\section{Statistical analysis}

We used STATA V.14.1 (StataCorp) to analyse the data. We applied 'svy' commands and sampling weights to adjust for the cluster sampling design in frequencies and cross-tabulations describing the study population, the primary exposure (maternal height), the maternal-level, child-level, household-level and community-level covariates, and the year of survey. Afterwards, we performed a multivariable modelling approach using 'Modified Poisson regression with robust error variance ${ }^{18}$ to estimate the association between outcome and main exposure adjusted for other covariates and recall periods. In this model building process, we first perform unadjusted univariable Poisson regression analysis between outcome and exposure or each of the covariates. We report the unadjusted relative risks (RRs) along with their 95\% CIs and $\mathrm{p}$ values. Based on the unadjusted analysis, we selected covariates with $\mathrm{p}<0.25$ along with the main exposure to build the base model for the multivariable modelling process. Then, we checked for collinearity between the variables selected for the base model. Finally, we constructed the multivariable Poisson regression models by a backward elimination method to identify the significant predictors of mortality along with maternal height. The level of significance was calculated at the $5 \%$ level using two-tailed Wald tests. For the continuous exposure and covariates, we checked the assumption of linearity with fractional polynomial and chose the appropriate parameterisation. ${ }^{19}$ We also performed multivariable Poisson regression with the final model adding all possible interactions between the main exposure and significant predictors and selected any significant interactions with $\mathrm{p}<0.01$ as a potential effect modifier for the full model. Then, we tested the full model for goodness of fit using both Pearson and deviance $\chi 2$ statistics. $^{20} 21$ If these tests were non-significant $(p>0.05)$, the model was considered as the best fitted for Poisson regression. Finally, we reported the findings from the multivariable models as adjusted RR, 95\% CIs and p values. We considered statistical significance as $\mathrm{p}<0.05$, and we presented the exact $\mathrm{p}$ value when $\mathrm{p}>0.001$.

\section{RESULTS}

Among 29698 singleton live births in the preceding five years of each survey, we excluded about $2 \%$ of the sample 
due to missing values for any of the covariates or biologically implausible outliers of the main exposure, maternal height, in the final analysis. For this study, we selected 29128 singleton live births for the final analysis. Among them, the number of neonatal deaths was 992 (34 per 1000 live births), infant deaths was 1373 (47 per 1000 live births) and under-five deaths was 1544 (53 per 1000 live births) (table 1). Nearly one in five neonatal and child deaths occurred among the children of women with short maternal height $(<145 \mathrm{~cm})$ (table 1$)$. The highest proportion of the neonatal $(38 \%)$ and under-five child deaths $(35 \%)$ occurred among the adolescent mothers aged $<20$ years. More than one in four neonates died whose mothers were illiterate, while the highest proportion of neonatal deaths $(37 \%)$ occurred among the newborn babies whose fathers were illiterate. Moreover, neonatal deaths occurred among about two-thirds of the mothers and more than half of the fathers whose education was either primary or secondary level. The highest proportion of child deaths occurred among the children of first birth rank, which was about $46 \%$ for neonatal mortality and nearly $40 \%$ for infant and under-five child mortality. The distributions of these covariates were also comparable across the maternal height categories among all under-five children (see online appendix supporting table 1).

This study also showed that the mean maternal height increased from $150.3 \mathrm{~cm}$ in 2004 to $150.9 \mathrm{~cm}$ in 2014 . There was no sign of an increasing gap between the wealthiest and poorest women as the gap in maternal height between these groups remained constant over the four surveys (figure 2). Our results showed that neonatal mortality was inversely associated with maternal height adjusted for maternal education, sex of the child, combined birth rank and interval and household wealth (table 2). In the adjusted model, every $1 \mathrm{~cm}$ increase of maternal height significantly reduced the risk of neonatal mortality by $3 \% \quad(\mathrm{RR}=0.973,95 \%$ CI 0.960 to $0.986, \mathrm{p}<0.001)$. Compared with the tallest mothers (height $\geq 155 \mathrm{~cm}$ ), the risk of neonatal mortality significantly increased about 1.73 times more among the children of the shortest mothers (height $<145 \mathrm{~cm})(\mathrm{RR}=1.73$, CI 1.31 to $2.28, \mathrm{p}=0.001$ ). The adjusted absolute probability of neonatal death was $2.6 \%$ for maternal height $\geq 155.0 \mathrm{~cm}$, while it was significantly increased to $3.1 \%$ for maternal height $154.9-150.0 \mathrm{~cm}, 3.5 \%$ for maternal height $149.9-145.0 \%$ and $4.4 \%$ for maternal height $<145$ $\mathrm{cm}(\mathrm{p}=0.001)$ (figure 3).

In the models adjusted for maternal education, occupation, combined birth rank and interval and household wealth, every $1 \mathrm{~cm}$ increase of maternal height significantly reduced about $2 \%$ for both under-five mortality $(\mathrm{RR}=0.982,95 \% \mathrm{CI} 0.972$ to $0.992, \mathrm{p}=0.001)$ and infant mortality $(\mathrm{RR}=0.980,95 \%$ CI 0.969 to $0.991, \mathrm{p}<0.001)$ (table 3). If we considered parent's education in the final models, both the mother's and the father's education were significant factors for under-five and infant mortality, but not household wealth. When we replaced the father's education with household wealth in the final model, as household wealth was correlated with father's education, the model showed household wealth as a significant factor for under-five and infant mortality (online appendix supporting table 2 and supporting table 3 ). In adjusted models, the risk of dying among the children with the short mothers (height $<145 \mathrm{~cm}$ ) was significantly higher at age under 5 years $(\mathrm{RR}=1.48,95 \% \mathrm{CI}$ 1.20 to $1.82, \mathrm{p}=0.001)$ and age less than 1 year $(\mathrm{RR}=1.60$, 95\% CI 1.28 to $2.01, \mathrm{p}<0.001)$ compared with those with the tallest mothers (height $\geq 155 \mathrm{~cm}$ ) (table 3$)$. The absolute probabilities of under-five and infant mortality were about $6.5 \%$ and $6.0 \%$ respectively for the children of short mothers, while these were about $4.4 \%$ and $3.7 \%$ respectively for children of tall mothers (table 3 ).

\section{DISCUSSION \\ Main findings}

Based on our analysis of a nationally representative sample, maternal height was inversely associated with neonatal, infant and under-five mortality in Bangladesh. Our results provided robust evidence that short maternal stature $(<145 \mathrm{~cm})$ substantially increased the risk of child mortality compared with taller maternal height $(\geq 155 \mathrm{~cm})$. Our study also showed a higher proportion of women with short stature among the poorest households compared with the wealthiest households. The mean maternal height increased from 2004 to 2014, and there was no sign of an increasing gap in mean maternal height, between women from the wealthiest versus the poorest households. The findings of this study are important because they provide evidence for child survival programmes and policies of the need to focus on maternal undernutrition as an underlying cause of child mortality in Bangladesh.

\section{Strengths and limitations}

This study has several strengths. First, it pooled data from four rounds of BDHS (2004, 2007, 2011 and 2014), thus providing large nationally representative samples with an average $98 \%$ response rate. ${ }^{22-25}$ Second, we restricted the data to children born in the five years preceding the survey date to minimise the recall bias. Third, we used Poisson regression models with robust variance as this is one of the less biased approaches to obtain correct estimates of the risk ratio for a dichotomous outcome like child mortality in biomedical research. ${ }^{26}$ Fourth, in the analysis, we considered a wide range of well-known risk factors for child undernutrition in the model to provide better estimates of the association between child mortality and maternal height. Fifth, the pooled analysis increased the study power, which allowed a full exploration of the effect of maternal height on mortality.

However, the study had several limitations that need to be considered while interpreting the results. As we used the data from cross-sectional surveys, our study only reported the association but not a causal relationship 
Table 1 Frequency distribution of the covariates among children dying in the neonatal, infant and under-five age groups and all live births

\begin{tabular}{|c|c|c|c|c|c|c|c|c|}
\hline \multirow[b]{4}{*}{ Covariates } & \multicolumn{6}{|c|}{ Child mortality } & & \\
\hline & \multicolumn{2}{|c|}{$\begin{array}{l}\text { Neonatal } \\
\text { (0-1 month) }\end{array}$} & \multicolumn{2}{|c|}{$\begin{array}{l}\text { Infant } \\
\text { (0-11 months) }\end{array}$} & \multicolumn{2}{|c|}{$\begin{array}{l}\text { Under-five } \\
\text { (0-59 months) }\end{array}$} & \multicolumn{2}{|c|}{ All livebirths } \\
\hline & \multicolumn{2}{|c|}{$\mathrm{N}=992$} & \multicolumn{2}{|c|}{$N=1373$} & \multicolumn{2}{|c|}{$N=1544$} & \multicolumn{2}{|c|}{$N=29128$} \\
\hline & $\mathbf{n}$ & $\%$ & $\mathbf{n}$ & $\%$ & $\mathbf{n}$ & $\%$ & $\mathbf{n}$ & $\%$ \\
\hline \multicolumn{9}{|l|}{ Maternal covariates } \\
\hline \multicolumn{9}{|l|}{ Maternal height, cm } \\
\hline$\geq 155.0$ & 165 & 15.8 & 236 & 16.4 & 273 & 17.1 & 6335 & 21.4 \\
\hline $154.9-150.0$ & 308 & 31.0 & 435 & 31.4 & 489 & 31.3 & 9892 & 33.6 \\
\hline $149.9-145.0$ & 328 & 33.5 & 440 & 32.6 & 498 & 32.9 & 8874 & 30.9 \\
\hline$<145.0$ & 191 & 19.8 & 262 & 19.5 & 284 & 18.7 & 4027 & 14.1 \\
\hline \multicolumn{9}{|l|}{ Maternal age at birth, years } \\
\hline$<20$ & 373 & 38.2 & 483 & 36.0 & 526 & 34.9 & 8237 & 29.0 \\
\hline $20-24$ & 306 & 30.9 & 411 & 29.5 & 472 & 30.3 & 9780 & 33.5 \\
\hline $25-29$ & 160 & 16.4 & 234 & 17.5 & 265 & 17.2 & 6286 & 21.5 \\
\hline 30 & 153 & 14.5 & 245 & 16.9 & 281 & 17.5 & 4825 & 16.1 \\
\hline \multicolumn{9}{|l|}{ Maternal educational level } \\
\hline No education & 280 & 28.4 & 447 & 32.8 & 512 & 33.0 & 7017 & 25.0 \\
\hline Primary & 310 & 31.3 & 432 & 30.4 & 483 & 30.2 & 8799 & 30.2 \\
\hline Secondary & 357 & 36.5 & 449 & 33.5 & 498 & 33.4 & 11023 & 38.0 \\
\hline Higher & 36 & 3.7 & 45 & 3.3 & 1212 & 3.4 & 2289 & 6.8 \\
\hline \multicolumn{9}{|l|}{ Mother's occupation } \\
\hline Not working & 792 & 78.6 & 1082 & 78.0 & 1212 & 77.7 & 23686 & 80.4 \\
\hline Working & 200 & 21.4 & 291 & 22.0 & 332 & 22.3 & 5442 & 19.7 \\
\hline \multicolumn{9}{|l|}{ Child covariates } \\
\hline \multicolumn{9}{|l|}{ Combined birth rank and interval } \\
\hline $\begin{array}{l}\text { Second/third birth rank, }>2 \text { years } \\
\text { interval }\end{array}$ & 264 & 27.5 & 375 & 28.6 & 431 & 29.1 & 11026 & 38.4 \\
\hline First birth rank & 457 & 45.7 & 565 & 41.2 & 610 & 39.5 & 10412 & 35.5 \\
\hline $\begin{array}{l}\text { Second/third birth rank, } \leq 2 \text { years } \\
\text { interval }\end{array}$ & 78 & 7.7 & 108 & 7.7 & 120 & 7.8 & 1592 & 5.4 \\
\hline $\begin{array}{l}\text { Fourth birth rank, }>2 \text { years } \\
\text { interval }\end{array}$ & 150 & 14.7 & 108 & 17.0 & 287 & 17.7 & 5143 & 17.6 \\
\hline $\begin{array}{l}\text { Fourth birth rank, } \leq 2 \text { years } \\
\text { interval }\end{array}$ & 43 & 4.4 & 75 & 5.5 & 96 & 6.0 & 955 & 3.1 \\
\hline \multicolumn{9}{|l|}{ Sex of the child } \\
\hline Male & 562 & 56.0 & 752 & 54.0 & 562 & 56.0 & 14914 & 51.1 \\
\hline Female & 430 & 44.0 & 621 & 46.0 & 430 & 44.0 & 14214 & 48.9 \\
\hline \multicolumn{9}{|l|}{ Household covariates } \\
\hline \multicolumn{9}{|l|}{ Wealth quintile } \\
\hline Fifth, richest & 135 & 12.1 & 188 & 23.5 & 214 & 13.2 & 5991 & 19.9 \\
\hline Fourth & 188 & 21.1 & 239 & 39.8 & 265 & 19.0 & 5654 & 20.0 \\
\hline Third & 200 & 20.8 & 278 & 30.0 & 314 & 20.7 & 5607 & 20.1 \\
\hline Second & 221 & 24.0 & 304 & 24.8 & 339 & 23.5 & 5387 & 20.0 \\
\hline First, poorest & 248 & 21.9 & 364 & 5.4 & 412 & 23.7 & 6489 & 20.0 \\
\hline Father's education & & & & & & & & \\
\hline
\end{tabular}


Table 1 Continued

\begin{tabular}{|c|c|c|c|c|c|c|c|c|}
\hline \multirow[b]{4}{*}{ Covariates } & \multicolumn{6}{|c|}{ Child mortality } & & \\
\hline & \multirow{2}{*}{\multicolumn{2}{|c|}{$\begin{array}{l}\begin{array}{l}\text { Neonatal } \\
(0-1 \text { month) }\end{array} \\
\mathrm{N}=992\end{array}$}} & \multirow{2}{*}{\multicolumn{2}{|c|}{$\begin{array}{l}\begin{array}{l}\text { Infant } \\
\text { (0-11 months) }\end{array} \\
\mathrm{N}=1373 \\
\end{array}$}} & \multirow{2}{*}{\multicolumn{2}{|c|}{$\begin{array}{l}\begin{array}{l}\text { Under-five } \\
\text { (0-59 months) }\end{array} \\
\mathrm{N}=1544\end{array}$}} & \multirow{2}{*}{\multicolumn{2}{|c|}{$\begin{array}{l}\text { All livebirths } \\
\mathrm{N}=29128\end{array}$}} \\
\hline & & & & & & & & \\
\hline & n & $\%$ & 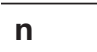 & $\%$ & $n$ & $\%$ & $\mathbf{n}$ & $\%$ \\
\hline No education & 368 & 37.2 & 539 & 39.8 & 609 & 40.0 & 9072 & 32.5 \\
\hline Primary & 306 & 30.1 & 419 & 30.0 & 477 & 30.5 & 8410 & 28.9 \\
\hline Secondary & 250 & 26.1 & 336 & 24.8 & 368 & 23.9 & 8008 & 27.2 \\
\hline Higher & 68 & 6.6 & 79 & 5.4 & 90 & 5.6 & 3638 & 11.4 \\
\hline \multicolumn{9}{|c|}{ Location of residence } \\
\hline Urban & 292 & 19.4 & 413 & 20.8 & 454 & 20.5 & 9143 & 22.1 \\
\hline Rural & 700 & 80.6 & 960 & 79.2 & 1090 & 79.6 & 19985 & 77.9 \\
\hline \multicolumn{9}{|l|}{ Region } \\
\hline Barisal & 93 & 5.1 & 131 & 5.1 & 156 & 5.3 & 3350 & 5.8 \\
\hline Chittagong & 171 & 18.4 & 247 & 19.6 & 305 & 21.8 & 5919 & 22.1 \\
\hline Dhaka & 182 & 31.4 & 262 & 32.1 & 287 & 31.1 & 5535 & 32.3 \\
\hline Khulna & 114 & 9.4 & 138 & 9.1 & 146 & 7.9 & 3378 & 9.1 \\
\hline Rajshahi & 157 & 19.0 & 206 & 16.1 & 224 & 17.3 & 4234 & 16.1 \\
\hline Sylhet & 163 & 10.7 & 242 & 9.6 & 267 & 10.9 & 4049 & 9.6 \\
\hline Rangpur & 112 & 6.1 & & & & & & \\
\hline \multicolumn{9}{|l|}{ Time (year) } \\
\hline 2004 & 270 & 28.5 & 415 & 31.4 & 478 & 32.3 & 6821 & 23.5 \\
\hline 2007 & 225 & 21.7 & 312 & 21.5 & 351 & 21.3 & 5958 & 20.0 \\
\hline 2011 & 277 & 27.0 & 358 & 25.1 & 398 & 24.9 & 8527 & 29.2 \\
\hline 2014 & 220 & 22.8 & 288 & 21.9 & 317 & 21.5 & 7822 & 27.3 \\
\hline
\end{tabular}

between maternal height and child mortality. The selection of covariates assessed in this study was driven by the data available in the BDHS data sets. For the data constraints, our study cannot examine the genetic and epigenetic factors, common confounders for maternal height and her offspring's health, to demonstrate how maternal height is linked to child health. Moreover, this study considered adult maternal height as a proxy indicator of her environmental exposure in the early stage of life and over the growing period. Due to data constraints
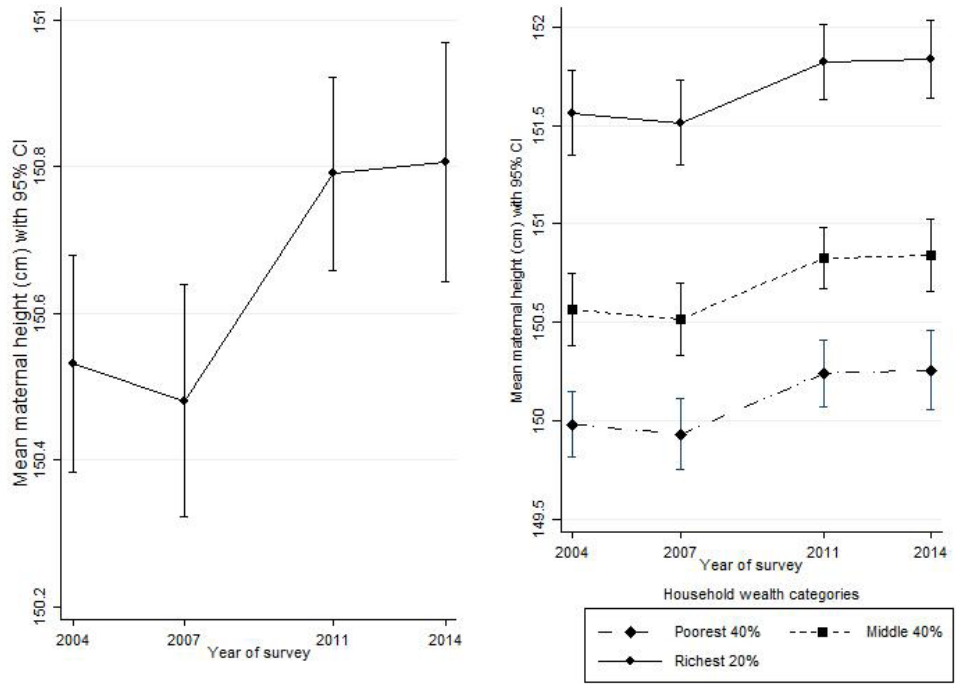

Figure 2 Mean maternal height $(\mathrm{cm})$ with $95 \% \mathrm{Cl}$ by year of survey and household wealth categories. 
Table $2^{*} \dagger$ Unadjusted and adjusted relative risks with $95 \% \mathrm{Cl}$ for the association between neonatal mortality and maternal height $(\mathrm{cm})$ adjusted for maternal and other covariates

\begin{tabular}{|c|c|c|c|c|c|c|c|}
\hline \multirow[b]{3}{*}{ Covariates } & \multirow[b]{3}{*}{$\mathbf{n}$} & \multicolumn{6}{|c|}{ Neonatal (0-1 month) mortality ( $\mathrm{N}=992)$} \\
\hline & & \multicolumn{2}{|l|}{ Unadjusted } & \multicolumn{2}{|c|}{ Adjusted model $1^{*}$} & \multicolumn{2}{|c|}{ Adjusted model $2 \dagger$} \\
\hline & & RR (95\% Cl) & $P$ values & RR (95\% Cl) & $P$ values & RR (95\% Cl) & $P$ values \\
\hline \multicolumn{8}{|l|}{ Maternal covariates } \\
\hline Maternal height per $1 \mathrm{~cm}$ increase & 992 & $\begin{array}{l}0.968 \\
(0.956 \text { to } 0.980)\end{array}$ & $<0.001$ & $\begin{array}{l}0.973 \\
(0.960 \text { to } 0.986)\end{array}$ & $<0.001$ & & \\
\hline \multicolumn{8}{|l|}{ Maternal height categories, $\mathrm{cm}$} \\
\hline$\geq 155.0$ & 165 & 1 (ref) & & & & 1 (ref) & \\
\hline $154.9-150.0$ & 308 & $\begin{array}{l}1.25 \\
\text { (1.01 to } 1.54)\end{array}$ & & & & $\begin{array}{l}1.22 \\
\text { (0.99 to } 1.51)\end{array}$ & \\
\hline $149.9-145.0$ & 328 & $\begin{array}{l}1.47 \\
(1.19 \text { to } 1.81)\end{array}$ & & & & $\begin{array}{l}1.41 \\
\text { (1.14 to } 1.74)\end{array}$ & \\
\hline$<145.0$ & 191 & $\begin{array}{l}1.90 \\
(1.46 \text { to } 2.47)\end{array}$ & $<0.001$ & & & $\begin{array}{l}1.73 \\
\text { (1.31 to } 2.28)\end{array}$ & 0.001 \\
\hline \multicolumn{8}{|l|}{ Maternal Age at birth, y } \\
\hline$<20$ & 373 & 1 (ref) & & & & & \\
\hline $20-24$ & 306 & $\begin{array}{l}0.70 \\
(0.59 \text { to } 0.83)\end{array}$ & & & & & \\
\hline $25-29$ & 160 & $\begin{array}{l}0.58 \\
(0.45 \text { to } 0.75)\end{array}$ & & & & & \\
\hline$\geq 30$ & 153 & $\begin{array}{l}0.69 \\
(0.55 \text { to } 0.85)\end{array}$ & $<0.001$ & & & & \\
\hline \multicolumn{8}{|l|}{ Maternal Educational level } \\
\hline No education & 280 & 1 (ref) & & $1(\mathrm{ref})$ & & 1 (ref) & \\
\hline Primary & 319 & $\begin{array}{l}0.91 \\
(0.76 \text { to } 1.09)\end{array}$ & & $\begin{array}{l}0.85 \\
(0.71 \text { to } 1.03)\end{array}$ & & $\begin{array}{l}0.85 \\
\text { (0.71 to } 1.03)\end{array}$ & \\
\hline Secondary & 357 & $\begin{array}{l}0.84 \\
(0.70 \text { to } 1.02)\end{array}$ & & $\begin{array}{l}0.80 \\
(0.64 \text { to } 0.99)\end{array}$ & & $\begin{array}{l}0.80 \\
\text { (0.64 to } 1.00)\end{array}$ & \\
\hline Higher & 36 & $\begin{array}{l}0.48 \\
(0.32 \text { to } 0.71)\end{array}$ & 0.003 & $\begin{array}{l}0.52 \\
(0.34 \text { to } 0.79)\end{array}$ & 0.015 & $\begin{array}{l}0.52 \\
(0.34 \text { to } 0.80)\end{array}$ & 0.018 \\
\hline \multicolumn{8}{|l|}{ Mother's Occupation } \\
\hline Not working & 792 & 1 (ref) & & & & & \\
\hline Working & 200 & $\begin{array}{l}1.12 \\
(0.94 \text { to } 1.33)\end{array}$ & 0.225 & & & & \\
\hline \multicolumn{8}{|l|}{ Child Covariates } \\
\hline \multicolumn{8}{|l|}{ Combined birth rank and interval } \\
\hline second/3rd birth rank, $>2$ years interval & 264 & 1 (ref) & & 1 (ref) & & 1 (ref) & \\
\hline first birth rank & 457 & $\begin{array}{l}1.80 \\
(1.48 \text { to } 2.18)\end{array}$ & & $\begin{array}{l}1.92 \\
(1.56 \text { to } 2.35)\end{array}$ & & $\begin{array}{l}1.92 \\
\text { (1.56 to } 2.36)\end{array}$ & \\
\hline second $/ 3$ rd birth rank, $<=2$ years interval & 78 & $\begin{array}{l}2.00 \\
(1.48 \text { to } 2.69)\end{array}$ & & $\begin{array}{l}1.93 \\
\text { (1.43 to } 2.59)\end{array}$ & & $\begin{array}{l}1.93 \\
\text { (1.43 to } 2.60)\end{array}$ & \\
\hline fourth birth rank, $>2$ years interval & 150 & $\begin{array}{l}1.17 \\
(0.91 \text { to } 1.49)\end{array}$ & & $\begin{array}{l}1.02 \\
(0.80 \text { to } 1.29)\end{array}$ & & $\begin{array}{l}1.02 \\
\text { (0.80 to } 1.29)\end{array}$ & \\
\hline fourth birth rank, $<=2$ years interval & 43 & $\begin{array}{l}1.96 \\
\text { (1.34 to } 2.86)\end{array}$ & $<0.001$ & $\begin{array}{l}1.71 \\
\text { (1.17 to } 2.48)\end{array}$ & $<0.001$ & $\begin{array}{l}1.71 \\
\text { (1.18 to } 2.49)\end{array}$ & $<0.001$ \\
\hline \multicolumn{8}{|l|}{ Sex of the child } \\
\hline Male & 562 & 1 (ref) & & 1 (ref) & & 1 (ref) & \\
\hline Female & 430 & $\begin{array}{l}0.82 \\
(0.71 \text { to } 0.95)\end{array}$ & 0.010 & $\begin{array}{l}0.83 \\
(0.71 \text { to } 0.96)\end{array}$ & 0.012 & $\begin{array}{l}0.83 \\
\text { (0.71 to } 0.96)\end{array}$ & 0.012 \\
\hline \multicolumn{8}{|l|}{ Household covariates } \\
\hline Wealth Quintile & & & & & & & \\
\hline
\end{tabular}


Table 2 Continued

\begin{tabular}{|c|c|c|c|c|c|c|c|}
\hline \multirow[b]{3}{*}{ Covariates } & \multirow[b]{3}{*}{$\mathbf{n}$} & \multicolumn{6}{|c|}{ Neonatal (0-1 month) mortality ( $\mathrm{N}=992)$} \\
\hline & & \multicolumn{2}{|l|}{ Unadjusted } & \multicolumn{2}{|c|}{ Adjusted model $1^{*}$} & \multicolumn{2}{|c|}{ Adjusted model $2 \dagger$} \\
\hline & & RR $(95 \% \mathrm{Cl})$ & $P$ values & RR (95\% Cl) & $P$ values & RR $(95 \% \mathrm{Cl})$ & $P$ values \\
\hline Fifth, richest & 135 & 1 (ref) & & 1 (ref) & & 1 (ref) & \\
\hline Fourth & 188 & $\begin{array}{l}1.74 \\
\text { (1.32 to } 2.29)\end{array}$ & & $\begin{array}{l}1.59 \\
\text { (1.20 to } 2.10)\end{array}$ & & $\begin{array}{l}1.58 \\
\text { (1.20 to } 2.08)\end{array}$ & \\
\hline Third & 200 & $\begin{array}{l}1.71 \\
\text { (1.34 to } 2.19)\end{array}$ & & $\begin{array}{l}1.51 \\
(1.17 \text { to } 1.95)\end{array}$ & & $\begin{array}{l}1.50 \\
(1.17 \text { to } 1.94)\end{array}$ & \\
\hline Second & 221 & $\begin{array}{l}1.97 \\
\text { (1.55 to } 2.51)\end{array}$ & & $\begin{array}{l}1.73 \\
\text { (1.33 to } 2.24)\end{array}$ & & $\begin{array}{l}1.72 \\
(1.32 \text { to } 2.23)\end{array}$ & \\
\hline First, poorest & 248 & $\begin{array}{l}1.80 \\
(1.42 \text { to } 2.29)\end{array}$ & $<0.001$ & $\begin{array}{l}1.57 \\
\text { (1.21 to } 2.04)\end{array}$ & 0.001 & $\begin{array}{l}1.56 \\
\text { (1.21 to } 2.02)\end{array}$ & 0.001 \\
\hline \multicolumn{8}{|c|}{ Father's Education } \\
\hline No education & 368 & 1 (ref) & & & & & \\
\hline Primary & 306 & $\begin{array}{l}0.91 \\
(0.77 \text { to } 1.08)\end{array}$ & & & & & \\
\hline Secondary & 250 & $\begin{array}{l}0.84 \\
(0.68 \text { to } 1.03)\end{array}$ & & & & & \\
\hline Higher & 68 & $\begin{array}{l}0.50 \\
(0.37 \text { to } 0.68)\end{array}$ & $<0.001$ & & & & \\
\hline \multicolumn{8}{|c|}{ Location of Residence } \\
\hline urban & 292 & 1 (ref) & & & & & \\
\hline rural & 700 & $\begin{array}{l}1.18 \\
\text { (1.01 to } 1.39)\end{array}$ & 0.043 & & & & \\
\hline \multicolumn{8}{|l|}{ Region } \\
\hline Barisal & 93 & 1 (ref) & & & & & \\
\hline Chittagong & 171 & $\begin{array}{l}0.94 \\
(0.72 \text { to } 1.23)\end{array}$ & & & & & \\
\hline Dhaka & 182 & $\begin{array}{l}1.10 \\
(0.84 \text { to } 1.45)\end{array}$ & & & & & \\
\hline Khulna & 114 & $\begin{array}{l}1.17 \\
\text { (0.88 to } 1.56)\end{array}$ & & & & & \\
\hline Rajshahi & 157 & $\begin{array}{l}1.33 \\
\text { (1.02 to } 1.75)\end{array}$ & & & & & \\
\hline Sylhet & 163 & $\begin{array}{l}1.26 \\
(0.96 \text { to } 1.65)\end{array}$ & & & & & \\
\hline Rangpur & 112 & $\begin{array}{l}1.38 \\
\text { (1.01 to } 1.88)\end{array}$ & 0.022 & & & & \\
\hline \multicolumn{8}{|l|}{ Time (year) } \\
\hline 2004 & 270 & 1 (ref) & & & & & \\
\hline 2007 & 225 & $\begin{array}{l}0.90 \\
(0.74 \text { to } 1.09)\end{array}$ & & & & & \\
\hline 2011 & 277 & $\begin{array}{l}0.76 \\
(0.63 \text { to } 0.92)\end{array}$ & & & & & \\
\hline 2014 & 220 & $\begin{array}{l}0.69 \\
(0.55 \text { to } 0.86)\end{array}$ & 0.003 & & & & \\
\hline Recall & 992 & $\begin{array}{l}0.997 \\
\text { (0.995 to } 1.000)\end{array}$ & 0.028 & & & & \\
\hline
\end{tabular}

Adjusted model for continuous maternal height.

Adjusted model for maternal height categories. 

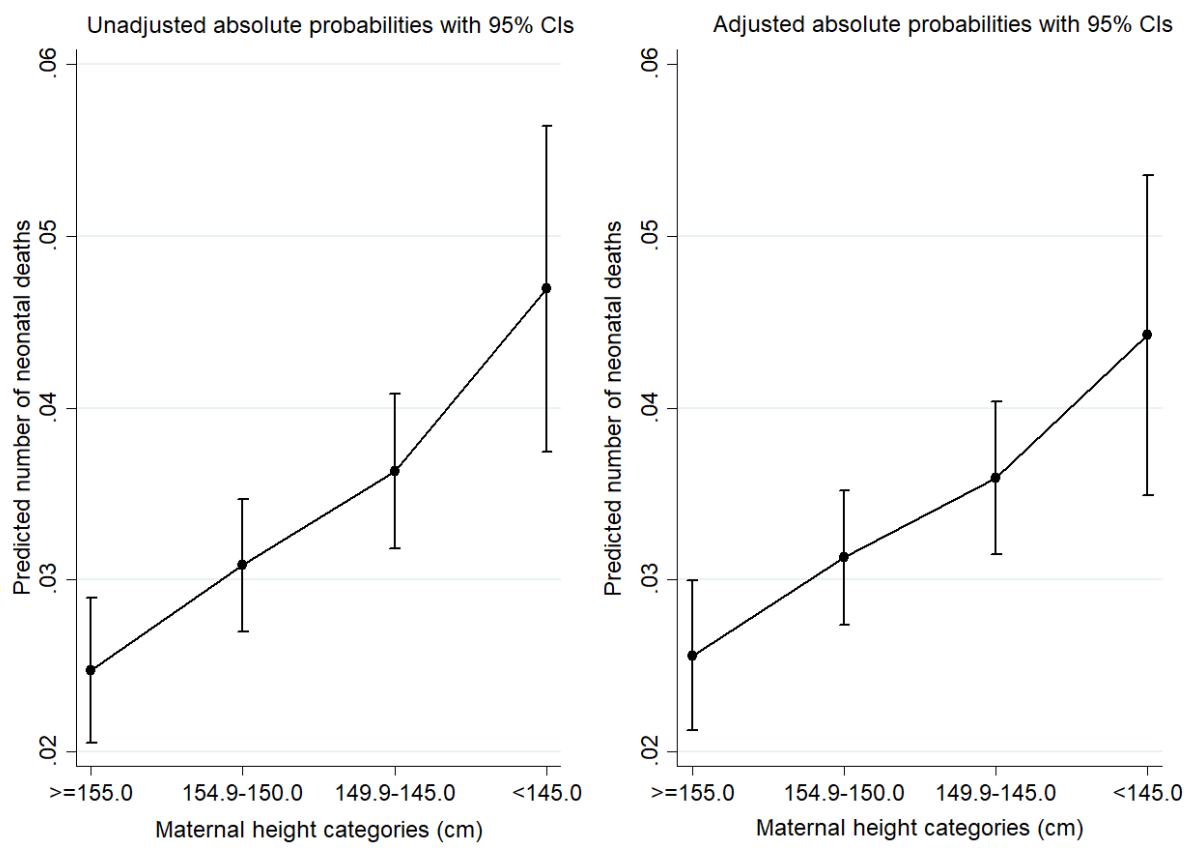

Figure 3 Unadjusted and adjusted absolute probabilities of neonatal mortality.

in BDHS, we could not consider information on maternal anthropometry or socioeconomic status in her childhood that would facilitate a more direct assessment of the intergenerational linkages in health. Another limitation was that these data sets only had the information about the surviving women and that might underestimate the relation between maternal and child mortality.

\section{Association between maternal height and offspring mortality}

Our study showed a robust inverse association between maternal height and neonatal and under-five mortality after adjustment for maternal, child and socioeconomic covariates. This finding was consistent to other studies from a neighbouring country, India, and other low-income countries. ${ }^{527}$ A large national survey (NFHS, 20052006) in India reported that each centimetre increase of maternal height was inversely associated with under-five mortality (RR $=0.978,95 \%$ CI 0.970 to 0.987$).{ }^{27}$ Similarly, another large study that pooled data from 54 low-income countries showed that each centimetre increase of maternal height significantly reduced the risk of neonatal mortality ( $\mathrm{RR}=0.982,95 \% \mathrm{CI} 0.981$ to 0.983 ) and underfive child mortality ( $\mathrm{RR}=0.988,95 \%$ CI 0.987 to 0.988$).^{5}$ Although this study included data from BDHS 1990-2007 in their pooled analysis, we presented the most recent data from the BDHS 2004-2014 with nationally representative sample. Therefore, this finding confirmed the strong evidence of intergenerational linkage between maternal height and child survival in the context of Bangladesh.

\section{Maternal short stature and risk of offspring mortality}

Similar to findings of earlier studies, our study also showed very strong evidence of an association between maternal short stature and risk of offspring mortality after adjustment for socioeconomic status. Moreover, this risk was greatest for maternal short stature $<145$ $\mathrm{cm}$. We also showed that the risk of offspring mortality gradually increased for the shorter mothers compared with the tall mothers whose height was $\geq 155 \mathrm{~cm}$. This finding was consistent with the pooled analysis of DHS data from 42 low-income countries in Asia and Africa, which showed that the hazard of child mortality progressively increased with the gradual decline of the maternal height from the average of $155 \mathrm{~cm} .{ }^{4}$ The linkage between short maternal height, socioeconomic status and the offspring's health can be explained by the four possible mechanisms as suggested in earlier research: (1) biomechanical (ie, narrower pelvic size, placental insufficiency or abruption); (2) biological (ie, poor nutrition stock, altered fetal metabolic programming); (3) genetic and (4) psychosocial (ie, low socioeconomic status or poor living standards). ${ }^{28} \mathrm{New}$ research on human development and epigenetics in human and animal studies has revealed that maternal undernutrition could impact on fetal programming through several pathways: (1) impaired placental growth; (2) insufficiency of placental to transfer essential nutrients to the fetus; (3) oxidative stress in both placenta and fetal; (4) epigenetic modification (ie, DNA methylation) to adapt with the adverse fetal environment; (6) altered genome activity and gene expression for fetal programming; and (7) alerted fetal programming causing impaired growth, development and immune function of the fetus through hormonal imbalance, metabolic disorder, organ dysfunction and defects in cell signalling. ${ }^{29}$ Evidence from an epidemiological study has reported an association between short 


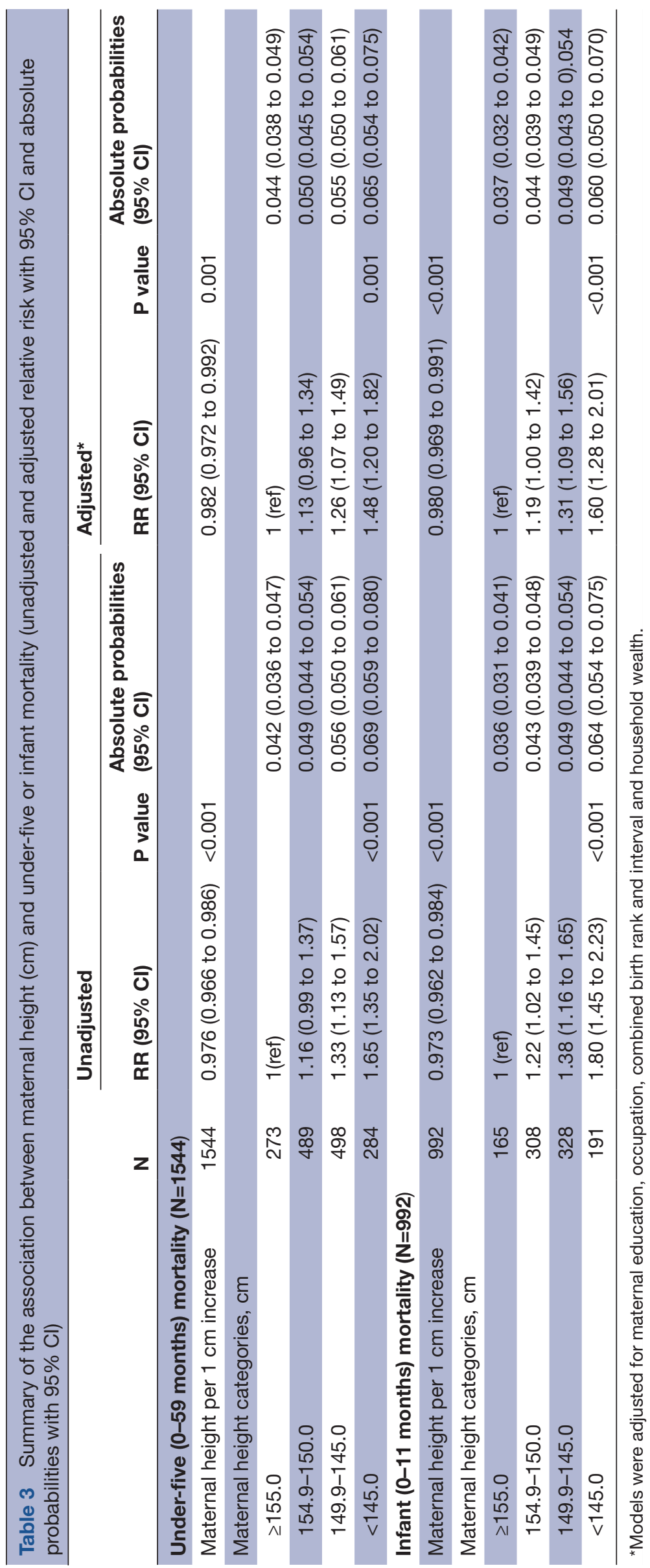


maternal stature and placental abruption, pre-eclampsia, preterm birth and SGA. ${ }^{31}$ Also, mothers who were SGA at birth due to her adverse environment, like low socioeconomic status, were more likely to deliver SGA babies and thus leading to an intergenerational transfer of poverty. ${ }^{32}$ Evidence from LMICs has revealed that SGA increases the risk of deaths by more than double for the term neonates and by about 15 times among the preterm neonates compared with the term appropriate for gestation age (AGA) babies. ${ }^{33}$ Moreover, low birth weight or SGA infants are also more likely to be stunted and wasted ${ }^{35}$ which increases their risk of cause-specific mortality due to a synergistic interaction between undernutrition and infections like pneumonia or diarrhoea. ${ }^{36}$ Thus, short maternal height leads to an increased risk of child mortality through preterm birth, fetal growth retardation and child undernutrition.

\section{Mean maternal stature over the time in the context of Bangladesh}

This study also showed that average maternal stature increased over the time from 2004 to 2014 in Bangladesh, but it was as little as less than $1 \mathrm{~cm}$. Although the country has made significant progress in reducing linear growth faltering among under-five children, the improvement in childhood growth is yet to reflect on adult maternal stature. We also found that there was no sign of an increasing gap between the wealthiest and poorest socioeconomic group over the last decade. However, the average maternal height was shorter among the poorest compared with the wealthiest socioeconomic group. A study that pooled data from 54 countries suggested that socioeconomic inequalities in women's stature remain persistent over the last few decades in low-income countries including Bangladesh. ${ }^{37}$ This study also showed that Bangladesh was among the five countries in the world where women's height on an average was shorter than the global mean height. Another recent study revealed that short maternal stature along with other socioeconomic covariates significantly contributed to socioeconomic inequality in stunting among under-five children in Bangladesh. ${ }^{38}$ Therefore, intergenerational effects can interact with social disparities resulting in growth faltering in childhood which would continue affecting adult short stature.

\section{Programme implications}

Our study is critical for Bangladesh, which has the highest proportion of women in the world with the short stature (height $<145 \mathrm{~cm}$ ), ${ }^{39}$ with more than 1 in 10 women being short in stature or stunted. ${ }^{40}$ The high burden of short stature implies that these women would have been deprived of optimal nutrition from an early to later stage of life and thus transfer undernutrition across the generations. However, we continue to neglect to address maternal undernutrition, especially short maternal stature, as a way to reduce cause-specific child mortality. Although Bangladesh has made substantial improvements in its health system, along with socioeconomic, environmental and educational improvements to reduce child mortality, ${ }^{41}$ there has been little progress in addressing the intergenerational effect of undernutrition to improve child health and survival. Recently, the United Nations System Standing Committee on Nutrition recommended improving maternal nutrition, even for short-statured women, through improvements in preconception or conception diet quality, to break the intergenerational cycle of growth faltering in utero leading to poorer child survival. ${ }^{42}$ Therefore, the current study findings draw attention to the programme and policymakers to focus on improving maternal nutrition for better offspring nutrition, health and survival. We also recommend evidence-based approaches of nutrition promotion and improved water and sanitation practices that have the potential to improve growth and break the vicious cycle of growth faltering in childhood. ${ }^{43}$ Although nutrition interventions have long-term consequences on adult height, improving the growth of girls is essential to reduce short maternal stature in Bangladesh. Therefore, these current study findings should draw the attention of the programme and policymakers to focus on improving maternal nutrition for better offspring nutrition, health and survival.

\section{CONCLUSION}

Our study showed maternal height was a strong predictor of child survival was inversely associated with neonatal, infant and under-five mortality in Bangladesh. Our results provided robust evidence that short maternal stature $(<145 \mathrm{~cm})$ substantially increased the risk of child mortality compared with taller maternal height $(\geq 155$ $\mathrm{cm})$. Although the poorest households had a higher proportion of women with short stature, compared with the wealthiest households, the short stature of adult women in this study is a proxy for their nutritional environment in utero and early childhood. Our findings suggest an important intergenerational linkage of the mother's nutritional status with the health and survival of her offspring.

Contributors WK had substantial contributions to conceptions, data collection, data analysis, interpretation of data and drafting the manuscript. TH had a contribution to data analysis. MJD, SR and AA contributed in revising it critically for valuable intellectual content. All authors read and approved the final manuscript.

Funding The authors have not declared a specific grant for this research from any funding agency in the public, commercial or not-for-profit sectors.

Competing interests None declared.

Patient consent Not required.

Ethics approval The institutional review board of ICF Macro in Calverton, MD, USA, approved ethics of the BDHS surveys.

Provenance and peer review Not commissioned; externally peer reviewed.

Data statement Bangladesh Demographic and Health Survey data are available at the public domain in https://dhsprogram.com/.

Open access This is an open access article distributed in accordance with the Creative Commons Attribution Non Commercial (CC BY-NC 4.0) license, which permits others to distribute, remix, adapt, build upon this work non-commercially, 
and license their derivative works on different terms, provided the original work is properly cited, appropriate credit is given, any changes made indicated, and the use is non-commercial. See: http://creativecommons.org/licenses/by-nc/4.0/

\section{REFERENCES}

1. UNICEF, WHO, World Bank Group, UN. Level \& Trends in Child Mortality. Report 2017. Estimates Developed by the Inter-agency Group for Child Mortality Estimation, 2017.

2. Black RE, Victora CG, Walker SP, et al. Maternal and child undernutrition and overweight in low-income and middle-income countries. Lancet 2013;382:427-51.

3. Kozuki N, Katz J, Lee AC, et al. Short maternal stature increases risk of small-for-gestational-age and preterm births in low- and middleincome countries: individual participant data meta-analysis and population attributable fraction. J Nutr 2015;145:2542-50.

4. Monden CW, Smits J. Maternal height and child mortality in 42 developing countries. Am J Hum Biol 2009;21:305-11.

5. Ozaltin E, Hill K, Subramanian SV. Association of maternal stature with offspring mortality, underweight, and stunting in low- to middleincome countries. JAMA 2010;303:1507-16.

6. Khan JR, Awan N. A comprehensive analysis on child mortality and its determinants in Bangladesh using frailty models. Arch Public Health 2017;75:58.

7. Abir T, Agho KE, Page AN, et al. Risk factors for under-5 mortality: evidence from Bangladesh Demographic and Health Survey, 20042011. BMJ Open 2015;5:e006722.

8. Demographic and Health Surveys, 2017. Available datasets. http:// dhsprogram.com/data/available-datasets.cfm (accessed 08 Aug 2017).

9. The DHS Programme, Demographic and Health Surveys, 2018. DHS overview. http://dhsprogram.com/What-We-Do/Survey-Types/DHS. cfm

10. International ICF. Demographic and health survey sampling and household listing manual. Calverton, Maryland, U.S.A: ICF International, 2012.

11. ICF. Demographic and health survey interviewer's manual. Rockville, Maryland, U.S.A: ICF, 2017.

12. Shireen A, Kothari MT, Pullum T. An assessment of the quality of dhs anthropometric data, 2005-2014. DHS methodological reports no. 16. Rockville, Maryland, USA: ICF International, 2015.

13. UNICEF, 2013. Improving Child Nutrition: The achievable imperative for global progress. https://www.unicef.org/publications/index 68661.html (accessed $10 \mathrm{Jul} 2018$ ).

14. The DHS Programme, 2018. Infant and child mortality. https:// dhsprogram.com/Topics/Infant-and-Child-Mortality.cfm.

15. Titaley CR, Dibley MJ, Roberts CL. Type of delivery attendant, place of delivery and risk of early neonatal mortality: analyses of the 19942007 Indonesia Demographic and Health Surveys. Health Policy Plan 2012;27:405-16.

16. Nisar YB, Dibley MJ. Determinants of neonatal mortality in Pakistan: secondary analysis of Pakistan Demographic and Health Survey 2006-07. BMC Public Health 2014;14:663.

17. Rutstein SO, Johnson K. The DHS wealth index: DHS comparative reports no.6. Calverton, Maryland: ORC Macro, 2004.

18. Yelland LN, Salter AB, Ryan P. Performance of the modified Poisson regression approach for estimating relative risks from clustered prospective data. Am J Epidemiol 2011;174:984-92.

19. Duong H C, Volding D. Modelling continuous risk variables: Introduction to fractional polynomial regression 2014:1-5.

20. STATA, 2017. poisson postestimation - Postestimation tools for poisson. https://www.stata.com/manuals/rpoissonpostestimation. pdf (accessed 13 Dec 2017).

21. Hayat MJ, Higgins M. Understanding poisson regression. J Nurs Educ 2014;53:207-15.

22. National Institute of Population Research and Training (NIPORT), Mitra and Associates, ICF International. Bangladesh demographic and health survey 2004. Dhaka, Bangladesh and Calverton, Maryland, USA: NIPORT, Mitra and Associates, and ICF International, 2005.

23. National Institute of Population Research and Training (NIPORT), Mitra and Associates, ICF International. Bangladesh demographic and health survey 2007. Dhaka, Bangladesh and Calverton, Maryland, USA: NIPORT, Mitra and Associates, and ICF International, 2009

24. National Institute of Population Research and Training (NIPORT), Mitra and Associates, ICF International. Bangladesh demographic and health survey 2011. Dhaka, Bangladesh and Calverton, Maryland, USA: NIPORT, Mitra and Associates, and ICF International, 2013.

25. National Institute of Population Research and Training (NIPORT) Mitra and Associates, ICF International. Bangladesh demographic and health survey 2014. Dhaka, Bangladesh and Calverton, Maryland, USA: NIPORT, Mitra and Associates, and ICF International, 2016.

26. Chen W, Shi J, Qian L, et al. Comparison of robustness to outliers between robust poisson models and log-binomial models when estimating relative risks for common binary outcomes: a simulation study. BMC Med Res Methodol 2014;14:82.

27. Subramanian SV, Ackerson LK, Davey Smith G, et al. Association of maternal height with child mortality, anthropometric failure, and anemia in India. JAMA 2009;301:1691-701.

28. Perkins JM, Subramanian SV, Davey Smith G, et al. Adult height, nutrition, and population health. Nutr Rev 2016;74:149-65.

29. Wang J, Wu Z, Li D, et al. Nutrition, epigenetics, and metabolic syndrome. Antioxid Redox Signal 2012;17:282-301.

30. Wu G, Imhoff-Kunsch B, Girard AW. Biological mechanisms for nutritional regulation of maternal health and fetal development. Paediatr Perinat Epidemiol 2012;26(Suppl 1):4-26.

31. Ogawa K, Morisaki N, Saito S, et al. Association of shorter height with increased risk of Ischaemic Placental disease. Paediatr Perinat Epidemiol 2017;31:198-205.

32. Martorell R, Zongrone A. Intergenerational influences on child growth and undernutrition. Paediatr Perinat Epidemiol 2012;26(Suppl 1):302-14.

33. Katz J, Lee AC, Kozuki N, et al. Mortality risk in preterm and small-for-gestational-age infants in low-income and middle-income countries: a pooled country analysis. Lancet 2013;382:417-25.

34. Ota E, Ganchimeg T, Morisaki N, et al. Risk factors and adverse perinatal outcomes among term and preterm infants born smallfor-gestational-age: secondary analyses of the WHO MultiCountry Survey on Maternal and Newborn Health. PLoS One 2014;9:e105155.

35. Christian P, Lee SE, Donahue Angel M, et al. Risk of childhood undernutrition related to small-for-gestational age and preterm birth in low- and middle-income countries. Int $J$ Epidemiol 2013;42:1340-55.

36. Olofin I, McDonald CM, Ezzati M, et al. Associations of suboptimal growth with all-cause and cause-specific mortality in children under five years: a pooled analysis of ten prospective studies. PLoS One 2013;8:e64636.

37. Subramanian SV, Özaltin E, Finlay JE. Height of nations: a socioeconomic analysis of cohort differences and patterns among women in 54 low- to middle-income countries. PLoS One 2011;6:e18962

38. Huda TM, Hayes A, El Arifeen S, et al. Social determinants of inequalities in child undernutrition in Bangladesh: a decomposition analysis. Matern Child Nutr 2018;14.

39. Black RE, Allen LH, Bhutta ZA, et al. Maternal and child undernutrition: global and regional exposures and health consequences. Lancet 2008;371:243-60.

40. International Food Policy Research Institute (IFPRI), 2015. Global Nutrition Report. 2015 Nutrition Country Profile. http://ebrary.ifpri. org/cdm/ref/collection/p15738coll2/id/129814 (accessed 08 Oct 2017)

41. Ministry of Health and Family Welfare, Bangladesh, Partnership for Maternal Newborn \& Child Health, WHO, World Bank, Alliance for Health Policy and Systems Research. Success factors for women's and children's health. Bangladesh, 2015.

42. UNSCN, 2017. 6th report on the world nutrition situation. Progress in nutrition. http://www.fao.org/3/a-as211e.pdf

43. Bhutta ZA, Das JK, Rizvi A, et al. Evidence-based interventions for improvement of maternal and child nutrition: what can be done and at what cost? Lancet 2013;382:452-77. 